\title{
The Economics of Science and Technology Policy
}

\section{Citation}

Freeman, Richard B. 2011. The economics of science and technology policy. In The Science of Science Policy: A Handbook, ed. Kay Husbands Fealing, Julia I. Lane, John H. Marburger III, and Stephanie Shipp, 85-103. Palo Alto, CA: Stanford University Press.

\section{Permanent link}

http://nrs.harvard.edu/urn-3:HUL.InstRepos:10488704

\section{Terms of Use}

This article was downloaded from Harvard University's DASH repository, and is made available under the terms and conditions applicable to Other Posted Material, as set forth at http:// nrs.harvard.edu/urn-3:HUL.InstRepos:dash.current.terms-of-use\#LAA

\section{Share Your Story}

The Harvard community has made this article openly available.

Please share how this access benefits you. Submit a story.

\section{Accessibility}




\title{
(cn:5
}

\section{@ct:The Economics of Science and Technology Policy}

\author{
@ca:Richard B. Freeman
}

\section{@h1:1. Introduction}

@ to:If you believe that long-term economic growth depends on the application of science and technology to the production of goods and services - and who in the knowledge economy does not? - then science lies at the heart of economic growth. Without increased scientific and technological knowledge, the economy would presumably end up in some static, steady state equilibrium - the economics equivalent of entropy. People would come and go, talking of Michelangelo, and the changing price of art would be the only interesting topic in economics. In his essay "Possibilities for Our Grandchildren" [1] Keynes painted such a vision of the world in the 2000s in which people had lots of time for leisure and culture but had little incentive to increase the stock of useful knowledge and apply it to create new goods and services and new ways to produce existing goods and services.

What differentiates the dynamic economy in which we live from the stasis of classical theory that Keynes painted for his grandchildren are society's investments in research and development $(\mathrm{R} \& \mathrm{D})$. Investment in basic research augments the stock of useful knowledge. Investment in applied research and development turn that knowledge into innovations that raise economic well-being. Science and technology policy help support this process and direct it to areas of social need. Economic incentives influence 
the career choice of students with respect to science/engineering and the decisions of firms to fund and commercialize research and of government R\&D initiatives. Analysis of the interactions between supply and demand and the feedback loops between economic needs and research activity and outcomes provide insight into the dynamic processes that make the whole system work and keep Keynes' classical economic vision of the future at bay. Finally, normative economic theory imbeds the analysis of science policy in the same welfare oriented framework that economists use to assess public policies and government interventions in market economies. This provides a logical framework for examining science's claim on social resources and for science of science policy.

In this chapter I consider the economics of supply and demand in the labor market for science and engineers, the way policy affects those two blades of Marshall's famous market scissors [2] to determine wages and employment of scientific-engineering workers, and some of the interactions and feed-backs in market dynamics.

\section{@1:2. Incentives and the Supply of Scientists and Engineers}

@ to: At the heart of the economic analysis of the supply of scientists and engineer is the response of economic agents, particularly young people choosing careers, to the incentives that society gives to select scientific work over other viable alternatives. Economics does not say that incentives in the form of high salaries, good job prospects, or the sometimes lucrative prizes and prestigious awards that go to star scientists are the only factor or the main factor in decisions to work in science. Economics is about choices on the margin. It recognizes that persons with particular skill sets or interests may be largely unresponsive to plausible changes in incentives. If you are a ten year old 
mathematical prodigy such as the young Terence Tao, it would take massive incentives to move you into investment banking or selling used cars instead of mathematics. Similarly, if you are a musical or athletic prodigy, it would take massive incentives to induce you to solve theorems instead of starring in the entertainment or sports worlds.

@tx: Persons on the margin between science and non-science work presumably have both the ability and interests to pursue either choice and are thus likely to be sensitive to pecuniary or other social rewards in making their choice. The greater the overlap in the skill set and interest of persons between science and viable alternatives, the greater will be the elasticity of supply to incentives. For instance, students who major in the biological sciences are often conflicted between becoming doctors or bio-medical research scientists. Students interested in creating innovative high tech businesses often view engineering and economics/business as alternative routes to that goal. As science has increasingly become a team activity and as more scientists and engineers form startup firms to turn their ideas into useful products, the overlap in skills that make someone good in science and good in business has presumably grown. From the other side, Wall Street firms hire "quants" with skills in mathematics and physics to develop and analyze financial instruments.

There are also skills that are valuable outside of science that have little payoff in science and, conversely, skills valuable in science that have little payoff in other fields. The talent that makes someone a great actor/actress or professional wrestler is unlikely to make them productive in science or math. And the talent that makes someone a great research scientist is unlikely to make that person a movie star or grappler in the squared circle. Because the critical skills are so different, science will lose little when a talented 
actor/actress chooses Hollywood or pro wrestling over Cal Tech, and conversely, Hollywood or wrestling will lose little by losing a math whiz to Cal Tech. ${ }^{\mathrm{i}}$

On net, whether increased incentives for science draws persons from outside science who are more or less able than current scientists and engineers depend on the correlation of the abilities that pay off in science and those that pay off in those other fields. If the skills are positively correlated, and the person on the margin chooses science, science gains someone likely to do especially well in science while the other field loses someone who could do well in its domain. Conversely, if the two skill sets are negatively correlated, the marginal person who moves between them will increase the average ability of persons in both fields.

Are enough young people on the margin between science and other fields so that policy interventions can substantially change the supply of scientists and engineers? Analysis of enrollments in various scientific fields, including physics, engineering, biology, and mathematics, shows that increased earnings, better scholarship and fellowship support, greater chances to attain the status of independent principal investigator, and the like, have large impacts on student decisions to enroll and graduate in science and engineering specialties [3]. In the annual survey of entering freshman conducted by UCLA's Higher Education Research Institute, students invariably report that monetary and career issues are important in choice of fields of study and careers [4].

Economists rarely question the idea that people respond to pecuniary incentives but there is a social psychology literature that warns that paying people to undertake certain actions can backfire by replacing or killing intrinsic motivation, which leads them to do less of that activity[5]. Choosing a career is not one of those activities. In the early 
1970s, when the job market for PhD physicists was particularly difficult, the Physics Department of the University of Chicago invited me to give a seminar on the supply and demand for physicists. I presented a regression-based analysis that linked enrollments in physics to the lagged earnings of physicists relative to other highly educated workers and related physicist earnings to past increases in supply and changes in R\&D spending [6]. The seminar chair criticized me for the naive belief that young physicists were motivated by anything other than love of science. Study physics for career reasons such as pay or job prospects? No dedicated scientist would let such mundane things affect him or her. We could have debated the merits or demerits of my regression analysis but the disagreement was settled by the graduate students and post-docs in the seminar. Troubled by their career prospects, the students booed and hissed the senior professor for failing to appreciate their concerns. This proved as well or better than any econometrics the validity of the economics approach to decisions to invest in scientific careers.

Evidence that improving pay and career prospects in science can increase the inflow of students into scientific fields notwithstanding, much U.S. policy discourse focuses on raising skills and interest in science among $\mathrm{K}-12$ students to expand the supply of scientists. Improvements in teaching science, mathematics, and engineering at the $\mathrm{K}-12$ level would surely benefit students and science but targeting people years before they make their career decisions is not an efficient way to increase supply in any policy-relevant time period. Since it takes much additional education for an eager $10^{\text {th }}$ grader to become a practicing scientist, someone motivated by better K-12 education would not appear on the job market for 10-15 years. Recognizing this, the National Academies of Science's 2010 Report on increasing the supply of underrepresented 
minorities in science made its top priority action to "increase undergraduate retention and completion through strong academic, social, and financial support [7]. What is true for underrepresented minorities is true for all students. Many more young people enter college and university with the background and intent to pursue science and engineering than ultimately do so. Many more major in science and engineering at the bachelor's level than go on graduate work in scientific disciplines. And many masters and $\mathrm{PhD}$ graduates in science and engineering who end up working outside of traditional scientific careers could be attracted into science and engineering activities with the appropriate incentives.

Considerable policy discourse also revolves around normative appeals for young people to choose science over other careers. Every few years, if not every year, leaders of the US scientific community and of the high-tech business world proclaim that the country faces a shortage of scientists and engineers. ${ }^{\text {ii }}$ The economy needs more scientists and engineers. High-tech firms need more. The future of humanity needs more. Whatever the actual needs of the economy, high-tech firms, and humanity, the lesson from economics is that if the country wants additional persons in scientific disciplines, it has to "put its money where its mouth is". Students compare working as a low wage post doctorate employee with uncertain prospects of a regular job to the high pay from business, law, medicine, or investment banking. It is difficult to induce those on the margin to choose science and engineering when the economics lies in the other direction.

Past experience shows that when the US increases incentives for investing in science and engineering, young people respond. In 1957, faced with the Sputnik challenge from the Soviet Union, the United States increased R\&D spending, which 
greatly raised the earnings and employment prospects of scientists and engineers. It awarded large numbers of National Science Foundation (NSF) graduate research fellowships (GRFs) and National Defense Education Act fellowships to encourage entrance into scientific careers. The booming job market and generous fellowships induced large numbers of young Americans to choose science and engineering.

Fast forward to the turn of the $21^{\text {st }}$ century. Despite a more than threefold increase in the number of bachelor's graduates in science and engineering, the NSF offered the same number of GRFs as it did in the 1950s. The value of the awards declined relative to other opportunities so that in 1999 the agency's Committee on Visitors concluded that "the GRF awards are no longer as attractive as they once were" [8]. The result was a drop in the proportion of science and engineering bachelors graduates applying for the fellowships. In response, the NSF raised the stipend value of the GRFs from $\$ 15,000$ in 1999 to $\$ 30,000$ in 2005. In 2010 it further increased the number of awards to 2,000. Figure 5.1 shows the relation between spending on the GRF relative to gross national product and the number of GRF applicants relative to science and engineering bachelor's graduates. Statistical analysis confirms the picture in the graph of relatively high elasticities of supply to the fellowship awards [9]. In fact, the increased value of GRFs induced other fellowship-granting organizations to raise the dollar value of their graduate science fellowships, which helped induce more US born or resident students into graduate science and engineering. But attracting more students into science and engineering will not necessarily keep them working in the fields if the increased supply depresses career earnings and employment opportunities when they graduate. 


\section{[Figure 5.1 ABOUT HERE]}

There have been two important changes in the demographic composition of the scientific work force from the 1960 s to the 2000 s.

The first is a large increase in the proportion of women getting higher degrees in science and engineering. In 1967, women earned $25 \%$ at bachelor's science and engineering degrees, $14 \%$ of master's level science and engineering degrees, and $8 \%$ of doctorate level engineering and science degrees [10]. Forty years later women earned $51 \%$ of science and engineering bachelor's degrees; $46 \%$ of science and engineering master's degrees, and 39\% of science and engineering $\mathrm{PhD}$ degrees [11]. By 2008 the female share of PhDs granted was 70\% in psychology and 53\% in the life sciences [12]. Approximately half of applicants and winners of the NSF GRFs were women, a far cry from the minimal numbers of female applicants and awardees when the program began in the 1950s. The female share of degrees in mathematical-intensive fields also increased but seemed to plateau at about $20 \%$ in the 2000 s. As a result women remained substantially underrepresented in the mathematical and computer science and architecture and engineering occupations [13].

The reasons fewer women than men are involved mathematics oriented activities has generated great controversy. In 2005 the then President of Harvard Lawrence Summers suggested that one possible explanation was that men and women differ in their mathematical abilities, possibly for some unknown innate reason. At one time men scored higher on tests of mathematical skills than women but this is no longer the case. Women have closed the gap in math test scores with men, and score the same or modestly higher than men in countries that have more female-friendly cultural 
climates.(14) The difference between the genders is in the variation of scores around the mean. Scores for men vary more than for women so that there are relatively more men at the bottom and at the top of the distribution[15]. The relatively larger number of men with very high scores presumably contributes to the difference between the allocation of men and women between more and less mathematical fields.

In almost all science and engineering fields, including those where the female proportion of graduates is around $50 \%$ or higher, women progress less rapidly than men in academic careers. Women are as likely to receive tenure track jobs upon receipt of a $\mathrm{PhD}$ but are less likely to gain tenure within ten years of the doctorate [16]. Why is this?

The most important factor is the structure of academic careers, which conflicts with the normal life cycle of family formation and child bearing and rearing for women. Consider the career path in the largest scientific field, life sciences. Life scientists earn their doctorates 8.6 years after graduating college (6.9 years for those who go immediately to graduate school) and typically work at postdoctoral job for 3 or more years. [17] This means that they are in their early to mid-thirties when they obtain their first full-time academic job, and in their late thirties or early forties when they come up for tenure. While some women have children and spend as much time on research as they did before the child, women that have children generally devote less time to research after the birth of the child and thus are likely to produce fewer papers than male peers in the years surrounding the tenure decision. By contrast, male scientists with young children tend to work more hours than they had in the past. The result is gender differences in rates of promotion. 
Another aspect of the career structure of academic science that is likely to discourage women is the tournament competition for limited slots and promotions. Academic science has many of the same attributes as golf or tennis tournaments, with competition on a reasonably clear criterion - in the case of science the production of knowledge as measured in publications and citations - that determines success in the form of promotions, research support, and so on[18]. Tournaments between people of comparable skills are an efficient way to incentivize work. But women with the abilities to win tournaments tend to eschew such competitions in favor of more cooperative work environments. By contrast, men, including those lacking the abilities to succeed in a tournament eagerly compete in tournaments [19]. The increased importance of teamwork in science may ultimately offset the effect of the tournament job market on women but thus far it has not done so fully.

As the supply of women with science degrees keeps growing, universities and firms face pressure to alter personnel and career practices that do not mesh with the greater share of women in the science talent pool. The challenge is to find ways to make the timing of career decisions and the careers themselves more female family friendly while maintaining the competitive pressures that drive scientific researchers.

The supply of scientists and engineers in the United States (and in most other advanced countries) has also changed greatly along one other dimension. This is in the national background of scientists and engineers. In the 1990s-2000s the number of international students and immigrant scientists and engineers from developing countries, particularly from India and China, increased substantially. Column 1 of Table 5.1 shows the great reliance of the United States on foreign-born persons in natural science and 
engineering, particularly at the graduate levels where over half of PhDs under 45 were born overseas.

\section{[TABLE 5.1 ABOUT HERE]}

Underlying the increase in immigrant scientists and engineers is the rapid expansion of higher education around the world. In $197029 \%$ of enrollments in higher education were in the US, which together with Canada, led the world in the number enrolled relative to the number of young persons. Thereafter, European countries increased their enrollments more rapidly than did the US, which dropped the US to the middle of the pack. In the 1990s hugely populous China and other developing countries began expanding their higher education systems. By the 2006 the US share of world enrollments in higher education had fallen to $12 \%$. [20]The growing number of science and engineering students world-wide greatly increased the potential number of immigrant scientists and engineers. Economic incentives in the form of better earnings and career opportunities in the US than in their home country created a fairly elastic supply of science and engineering specialists to the US, particularly from developing countries.

The attraction of American institutions of higher education for graduate study also contributed to the increased supply of foreign-born scientists and engineers. Many international students remain in the country after they graduate. The earlier they comeas undergraduates rather than graduate students, or as high school students rather than undergraduates - the more likely international students migrate to the country. Column 2 of Table 1 shows that huge proportions of foreign-born scientists and engineers obtained their highest degree in the United States. Policy toward international students and immigration are thus a part of science and technology policy. 
Experienced researchers also respond to economic incentives. They do so in choosing the employer or sector in which they work and in the research topics on which they work. If industry or government agencies invest in a research area, scientists and engineers will shift their research to that area. The War on Cancer induced researchers to work on medical science issues related to cancer. The National Nanotechnology Initiative spurred increased research on nanotechnology projects. Indicative of this responsiveness, when the National Institutes of Health (NIH) announced in 2009 that it was allocating \$200 million to fund 200 or more special challenge grants to researchers outside of its normal grant process, the agency received over 21,000 applications. Medical scientists from one institution, the University of Minnesota Healthcare Partners, applied for 50 awards for \$19.1 million in March 2009, 489 awards for \$331.8 million in April 2009, and 17 awards for $\$ 21.1$ million for May $1-5,2009$. NIH had to rapidly recruit over 18,000 scientists to peer review the proposals. Scientists follow the scientific and technological opportunities and their own ideas and interests but they also follow the money in deciding what to research.

Perhaps the most important change in the nature of scientific work, with huge implications for the science of science policy is the shift from a world in which most scientists worked as lone investigators, perhaps with a laboratory assistant or two, to the current world in which most scientists and engineers work in large teams. Analysis of the productivity of scientists has traditionally focused on individual productivity. Since Lotka's 1926 study of the number of scientific publications of chemists and physicists [21], analysts have documented that a few scientists contribute the most research papers, that a few papers gain the most citations, etc, so that scientific productivity follows a 
power law with a long fat tail. These studies fit well with a model of science in which the "stars" are the prime movers of knowledge. They suggest that policy should identify potential stars as quickly as possible and reward them with money or grants.

But over time the predominance of lone investigative work has declined. The number of persons working on scientific projects has increased greatly. In 2000 the typical paper in the sciences listed 3.5 authors, with variation among fields, compared to 1.9 authors in 1995 [22]. Scientometric evidence on patterns of co-authorship and citations highlight the links among scientists and the paper trail of their work have led to a new network analysis of the development and transmission of knowledge. Network studies fit well with a model of science which places social interactions at the heart of scientific progress. If what matters for progress is a dense network of researchers, policymakers should spread resources more widely.

The changing nature of scientific work raises important questions that readily fit with economic analysis. What incentives lead scientists to collaborate with others? How does the allocation of credit in team-based production affect the career path of scientists, particularly younger persons just beginning their research lives? What determines the productivity of teams of scientists? What is the optimal composition of a team? How does the formation of post-doctoral associations and unions to protect the interests of younger researchers affect their pecuniary and non-pecuniary work conditions? What kinds of work relations will emerge in the new world of team science? Economists concerned with science have not yet focused on these questions but they surely will. @h1:3. Demand for Scientists and Engineers 
@to: Institutions of higher education hire scientists and engineers to do research, usually on grants that the scientists and engineers raise themselves, and/or to teach and mentor the next generation of scientists and engineers. In the US universities conduct the bulk of basic research, much of which is government funded. In Germany and some other countries, government funds more basic research at research institutes independent of universities.

Industry hires scientists and engineers to design and develop new commercial products or processes based on scientific advances or to help implement or spread those products or processes in ways that increase profits. Table 5-2 shows that in the United States and in most other advanced countries, private industry undertakes the preponderance of $R \& D$ spending and thus hires most research scientists and engineers. In in 2008 , business funded 67 percent of US R\&D and conducted 73 percent of R\&D, the difference resulting from substantial government support for industrial research [23].

Much like industry, the government hires scientists and engineers for missionoriented projects to further specific goals. Sixty-one percent of total government R\&D is for defense, 21 percent for health, and 6 percent for space, compared to 6 percent for general science. Still through mission-oriented R\&D as well as support of general science the federal government funded 57 percent of U.S. basic research in 2008.

\section{[TABLE 5.2 ABOUT HERE]}

@tx: In addition to funding research, government affects R\&D through the patent protection that it gives to new discoveries or inventions. Patents give the inventor or discoverer monopoly rights over the new knowledge for the period of the patent. 
Economists analyze patents in term of the trade-off between the static inefficiency from the temporary monopoly and the dynamic efficiency from the incentive that patents give to knowledge creation[24, 25]. In the absence of patents the only way firms could keep others from poaching their trade secrets would be through industrial secrecy. They would only research areas that could be so protected, and thus would do less research than if they could have legal protection through a patent. Another disadvantage of industrial secrecy is that it could in principle last forever, which would deprive others of the knowledge and opportunity to improve on the invention. But patents do not protect all knowledge associated with R\&D. To prevent researchers with leading edge knowledge from taking this knowledge to a competitor, many firms require employees to sign non-compete agreements. These are legal documents in which the employees agree that they will not undertake similar work elsewhere for some period of time. State law governs the enforcement of non-compete agreements. Some states such as Massachusetts enforce these agreements. Others such as California have made them invalid. This has consequences for the location and nature of inventors' activities. [26]

In 1980 Congress decided that universities receiving federal research grants were too slow in commercializing inventions or discoveries from those grants. To encourage universities to be more pro-active, it enacted the Bayh-Dole Act, which allowed them to file for patent protection on findings from government funded research. This was part and parcel of a general movement in the 1980s and 1990s to strengthen patent protection. While the overall effort has received mixed reviews from economists [24], the Bayh-Dole Act is widely viewed as successful in getting university researchers to try to move their discoveries more rapidly into commercial use. [27] 
Another way to induce private actors to undertake R\&D and make the knowledge public is to run a prize competition which gives large monetary prizes to those who succeed in making the relevant discovery. As an example of such a prize system, the Xprize Foundation offered ten million dollar prizes in the 2000s for inventors who achieved goals that it viewed as having "the potential to benefit humanity" such as a spacecraft, lunar explorer, or a more efficient automobile (http://www.xprize.org/). Some analysts suggest that prizes should also be used to spur pharmaceutical companies to develop drugs for rare diseases or diseases in developing countries where incomes are too low to justify a profit-making firm seeking to cure the disease. [28]

Economists also study how firms respond to tax write-offs for R\&D. Whenever the government tax advantages a particular activity firms have incentives not only to increase that activity but also to re-label other activities to fit under the tax break. This creates a problem in estimating the impact of changes in taxes on actual R\&D. But the problem is manageable. In 2000 Bronwyn Hall and John Van Reenen reviewed studies of R\&D tax credits in many countries and concluded that firms did indeed respond by undertaking more real research to the $\mathrm{R} \& \mathrm{D}$ tax credits[29]. There is thus evidence of demand responsiveness to policy-induced incentives comparable to the evidence of supply responsiveness.

Economic analysis of the demand for R\&D highlights the ways in which investment in knowledge differs from investment in tangible capital goods. Knowledge has the properties of a public good, in that once it is made public, there is no way to exclude firms or researchers from using it (beyond the patent system) and in that one 
person's use does not deplete it for others [30]. To the contrary, the more people that use a body of knowledge the more likely someone will improve on it.

The information created by $\mathrm{R} \& \mathrm{D}$ distinguishes investments in research from investments in tangible physical capital in an important way. As a firm or principal investigator learns from initial research whether a particular research path is or is not promising, it has the option of deciding whether or not to pursue that path further. Many firms such as those in the pharmaceutical industry divide R\&D projects formally into stages $^{\mathrm{iii}}$ that reflect this aspect of research. These firms do not fund the entire project on the basis of its having a positive expected net present value at the outset. If the project goes well, the firm proceeds. If the project goes poorly, it pulls the plug on the project and saves money. This is similar to an option in finance, where the investor buys the right to buy or sell some item in the future when the investor will have better knowledge of its value. Potentially risky projects with an expected negative net present value today may turn out to be profitable through the lens of an option. Since the value of options rises with variance in potential returns, the option perspective leads firms and principal investigators to undertake riskier potentially transformative research than they would otherwise do. Although few firms explicitly base R\&D decisions on the mathematics of option valuation [31], evidence that returns to $R \& D$ are highly skewed $[32,33]$, with the bulk of returns coming from relatively few projects, has the hallmark of option behavior.

Research and development spending can also be viewed from the perspective of portfolio analysis, which stresses the value of diversification in investing in different assets or projects to reduce risk. Measuring risk by the variance of returns, the formula for the summation of variances shows that undertaking different projects that have low 
positive correlated returns or better yet negatively correlated returns reduces the total risk. Since R\&D is risky and firms/researchers/government program officers are presumably risk averse, the economics recommendation is that decision makers do better to form portfolios of projects rather than put all their money into the most promising one.

\section{[FIGURE 5.2 ABOUT HERE]}

\section{@h1:4. The Dangers of Volatile R\&D Spending}

@ to: In the macro-economy private investment is the "squeaky wheel" that produces recessions while government spending is the stabilizer that dampens private sector fluctuations. In R\&D the opposite is true. Government spending is the volatile component while private industry spending is the stabilizer. In the US the ratio of government funded $R \& D$ to gross domestic product has varied substantially over time as policy priorities changed. The ratio rose in the late 1950s and early 1960s as the government responded to Sputnik. It dropped in the late 1960s when the government cutback defense and space programs, stabilized in the late 1970s as the government increased R\&D for energy in response to the 1970s oil price shock, then fell in the late 1980s when the government cut defense-related and energy-related R\&D. Federal spending increased sharply for bio-medical sciences after President Clinton and Congress agreed in 1997 to double the nominal budget of the National Institute of Health over the next five years. President Bush completed the doubling in 2003 but then stabilized the budget so that real NIH spending fell over the remainder of his term as President. This effectively negated the expansionary impact of the doubling. Three years into the postdoubling squeeze of $\mathrm{NIH}$, the biomedical research community was in an uproar over the 
harm that the decline in real spending was having. According to Whitehead Institute founder Robert Weinberg, "The marvelous engine of American biomedical research that was constructed during the last half of the 20th century is being taken apart, piece by piece" [34]. Elias Zerhouni, Bush's director of NIH, expressed alarm at the effect of the cutbacks on the careers of entering bio-medical scientists: "Without effective national policies to recruit young scientists to the field, and support their research over the long term, in 10 to 15 years, we'll have more scientists older than 65 than those younger than 35. This is not a sustainable trend in biomedical research and must be addressed aggressively" [35].

@ tx:The NIH experience highlights two problems with volatile government R\&D spending. The first is that large spending increases are likely to increase the costs/reduce the productivity of research compared to more gradual increases in spending. Rapid buildups in $\mathrm{R} \& \mathrm{D}$ produce larger increases in costs than gradual buildups because it takes time for people and resources to meet the new demand, and because costs tend to rise non-linearly in the short run. This means less output for the research dollar. The second problem is that rapid increases must level off, and when they do, this invariably leaves some people and projects caught in the pipeline. During the doubling period many more scientists applied for lucrative grants (that supply responsiveness again), but the number of applications rose even more in the aftermath as researchers who feared that their careers would end without further support applied several times for the scarce funds. The $\mathrm{NIH}$, which is the single largest employer of biomedical researchers in the United States, with more than 1,000 principal investigators and 6,000 to 7,000 researchers, cut employment of principal investigators by 9 percent in the post-doubling period. 
The costs of the volatile R\&D spending are mindful of the costs of volatile capital spending in the classic business cycle accelerator model of investment. In the accelerator model, an increase in demand for output induces firms to seek more capital stock to meet the new demand. This increases investment spending. When firms reach the desired level of capital stock, they stop investing, save to replace decaying capital. The equivalent of demand for output in research is federal R\&D spending. The equivalent of investment spending is the creation of jobs for new researchers. As Zerhouni correctly observed, it is the young people who build their skills as graduate students or post docs during the acceleration phase of spending and bear much of the cost of the deceleration.

Following the onset of the Wall Street implosion and ensuing recession President Obama's American Recovery and Reinvestment Act (ARRA) stimulus package included $\$ 20.5$ billion in additional research funding. The stimulus to science was initially set at $\$ 14.0$ billion, but in the conference committee reconciling the House and Senate versions of the bill, Senator Spector of Pennsylvania added $\$ 6.5$ billion for the NIH. Figure 5.2 shows the pattern of change in NIH spending from 1995 through 2010 and the proposed 2011 budget. The burst of ARRA money for research followed by a huge post-2010 cutback has the potential to create a problem comparable to that which followed the doubling of NIH spending from 1998 to 2003. But having learned from the NIH doubling experience, agencies, universities, and principal investigators have sought ways to smooth the spending of funds and buffer the drop off in spending when ARRA ends. Knowing that this burst of spending is temporary will at the minimum prevent the shock that occurred when the NIH doubling ended. 
If ever there was a science policy problem where economics can help policy makers, it is in finding ways to avoid the "falling off the cliff" scenario at the end of a burst of spending.

\section{@h1:5. Conclusion: How Much Should the Public Support R\&D?}

@to: How should a taxpayer evaluate the billions of dollars that the U.S. government spends on R\&D directly or indirectly by awarding patents or tax credits or subsidies for private research and development activities?

The economics answer is to examine the rate of return to R\&D spending. Many economic studies of $R \& D$ use production functions to estimate the impact of $R \& D$ on outcomes and to assess its rate of return. Because it is difficult to trace the effects of basic research on output these studies focus on private rates of return to firm-based R\&D. They typically relate a firm's sales or value added to labor, physical capital, and an estimate of its "knowledge capital" based on its R\&D expenditures and an assumed rate of depreciation of the $R \& D$ created knowledge. Firms that invest in $R \& D$ have higher output [36], which translates into a reasonably high rate of return to the investment. Estimates that look for spillovers from one organization's R\&D to others, which are not captured in its sales or profits, suggest even higher social rates of return.

@tx: The production function methodology is an incomplete analysis of the social payoff to science. As noted, it does not assess the value of the basic research. It does not address the impact of the increased spread of scientific and economic competence around the world on the payoff from research. In a global world, where knowledge travels rapidly and where multinationals locate production in low wage countries, the 
"stickiness" of knowledge to the locale that undertakes the research has greater salience than when the United States and other advanced countries had a near monopoly in high tech areas. Multinationals are concerned with their return to $R \& D$, not to whether the return benefits the country in which they do the R\&D or any other particular locality. Putting these issues aside, economic analysis of R\&D still provides at best only crude guidance to the payoff from future research programs. The reason is that $R \& D$ has, by its very nature, highly uncertain outcomes. Research is a voyage into the unknown, so that even well-determined estimates of returns from past spending may not be indicative of future returns. Still economics has much to contribute to the science of science policy. Studies of the supply of persons to scientific activities and of the factors that influence R\&D spending have implications for the effectiveness of policy tools and the way they operate by changing incentives. The economic analysis also lays out ways for policymakers to think about how much and in what ways to support scientific research directed toward social goals. Ideally, scientific investigation that proceeds sequentially yields a distribution of future outcomes with a long positive "tail", which can help policymakers pattern research support to reflect the option value of the research. And, as befits any research-based topic, it highlights important areas in which further research can advance the goal of making science policy more scientific.

\section{@h1:References}

@bib: 
[1] Pecchi, Lorenzo, and Gustavo Piga, eds., Revisiting Keynes: Economic Possibilities for Our Grandchildren (Boston, MA: MIT Press, 2008) contains the original article and the thoughts of modern economists.

[2] A. Marshall. Principles of Economics (published 1890): Book Five: General Relations of Demand, Supply and Value. Marxist Internet Archives. Available from:http://www.marxists.org/reference/subject/economics/marshall/bk5ch03.htm.

[3] Richard B. Freeman. The Market for College Trained Manpower Harvard University Press, 1971

[4] UCLA, Higher Education Research Institute, Freshman Survey http://www.heri.ucla.edu/cirpoverview.php

[5] Alfie. Kohn. Punished by Rewards: The Trouble with Gold Stars, Incentive Plans, A's, Praise, and Other Bribes. Boston (MA): Houghton, Mifflin and Company; 1993.

[6] Richard B. Freeman. Supply and Salary Adjustments to the Changing Science Manpower Market: Physics, 1948-1973. The American Economic Review, 65;1975;2739.

[7] National Academy of Sciences, National Academy of Engineering, and Institute of MedicineCommittee on Underrepresented Groups and the Expansion of the Science and 
Engineering Workforce Pipeline; Committee on Science, Engineering, and Public Policy; Policy and Global Affairs; Expanding Underrepresented Minority Participation: America's Science and Technology Talent at the Crossroads National Academies Press 2010, p 9

[8]Committee of Visitors, Report of the committee of visitors, National Science Foundation, Graduate Research Fellowship Program, June 17-18, 1999

[9]Freeman, Richard B, Tanwin Chang, and Hanley Chiang, "Supporting "the best and brightest" in Science and Engineering: NSF Graduate Research Fellowships" in Richard Freeman and Daniel Goroff, Science and Engineering Careers in the United States (University of Chicago Press, 2010)

[10] U.S. National Science Foundation, NSF-08-321, Science and Engineering Degrees: 1966-2006, October, 2008, table 3

[11] US Bureau of the Census, Statistical Abstract 2010, table 788

[12] U.S. National Science Foundation, Doctorate Recipients from U.S. Universities: Summary Report 2007-08 Special Report | NSF 10-309 | December 2009, table 7

[13] US Bureau of the Census Statistical Abstract 2010 Table 603. Employed Civilians by Occupation, Sex, Race, and Hispanic Origin: 2008 
[14] Hyde, Janet S. and Janet E. Mertz Gender, culture, and mathematics performance PNAS June 2, 2009 vol. 106 no. 22 8801-8807; Luigi Guiso, Ferdinando Monte, Paola Sapienza and Luigi Zingales, : 'Culture, Gender and Math 'Science 30 May 2008:Volume 320(5880): 1164-5.

[15]Machin, Stephen and Tuomas Pekkarinen, Global Sex Differences in Test Score

Variability' Science 28 November 2008:Volume 322 (5906):

\section{$1331-2$}

[16] Ginther, Donna K., Schaffer, Walter T. , Schnell, Joshua, Masimore, Beth, Liu, Faye, Haak, Laurel L. and Kington, Raynard S. , Diversity in Academic Biomedicine: An Evaluation of Education and Career Outcomes with Implications for Policy (September 22, 2009). Available at SSRN: http://ssrn.com/abstract=1677993. Also see Donna Ginther and Shulamit Khan "Does Science Promote Women? Evidence from Academia 1973 2001" (2009) Science and Engineering Careers in the United States. Richard B.

Freeman and Daniel F. Goroff (eds), Chicago, IL: University of Chicago Press for NBER Science Engineering Workforce Project

[17] National Science Foundation, Doctorate Recipients from U.S. Universities: Summary Report 2007-08 Special Report | NSF 10-309 | December 2009 http://www.nsf.gov/statistics/nsf10309/pdf/tab18.pdf) 
[18] Richard Freeman, Eric Weinstein, Elizabeth Marincola, Janet Rosenbaum, Frank Solomon. CAREERS: Competition and Careers in Biosciences. Science, 294;2001;22932294.

[19] Niederle, Muriel and Lisa Vesterlund. Do Women Shy Away from Competition? Do Men Compete Too Much? Quarterly Journal of Economics, 122;2007;1067-1101. Also “ Explaining the Gender Gap in Math Test Scores: The Role of Competition" Journal

of Economic Perspectives-Volume 24, Number 2-Spring 2010Pages $129-144$

[20] UNESCO on-line data files, as calculated by author

[21] A.J. Lotka, 'The Frequency Distribution of Scientific Productivity', Journal of the Washington Academy of Science, Vol. 16 (1926), 317-23.

[22] Wuchty, Stefan, Benjamin F. Jones, Brian Uzzi "The Increasing Dominance of Teams in Production of Knowledge" Science 18 May 2007: Vol. 316. no. 5827, pp. 1036 - 1039

[23] M. Boroush. New NSF Estimates Indicate That U.S. R\&D Spending Continued to Grow in 2008. Washington (DC): National Science Foundation; 2010. Also National Science Board. 2010. Science and Engineering Indicators 2010. Arlington, VA: National Science Foundation (NSB 10-01). Appendix table 4-4. 
[24] A. Jaffe, J. Lerner. Innovation and Its Discontents: How Our Broken Patent System Is Endangering Innovation and Progress and What To Do About It. Princeton (NJ): Princeton University Press; 2002.

[25] A. Jaffe, M. Trajtenberg. Patents, Citations, and Innovations: A Window on the Knowledge Economy. Cambridge (MA): MIT Press; 2002.

[26] Marx Matt, Deborah Strumsky, Lee Fleming "Mobility, Skills, and the Michigan Non-Compete Experiment” MANAGEMENT SCIENCE Vol. 55, No. 6, June 2009, pp. $875-889$

[27] Committee on Management of University Intellectual Property: Managing University Intellectual Property in the Public Interest Lessons from a Generation of Experience, Research, and Dialogue; Stephen A. Merrill and Anne-Marie Mazza, Editors; National Research Council

[28] Michael Kremer, Patent Buyouts: A Mechanism for Encouraging Innovation, 113 Q.J. ECON. 1137 (1998); also see http://www.cato.org/pubs/regulation/regv23n2/kremer.pdf

[29] B. Hall, J. Van Reenen. How Effective Are Fiscal Incentives for R\&D? A Review of the Evidence. Research Policy, 29;2000;449-469. 
[30] Paula Stephan "Economics of Science" http://dimetic.dimeeu.org/dimetic_files/Economics.of_.Science.August24.07.pdf

[31] M. Hartmann, A. Hassan. Application of Real Options Analysis for Pharmaceutical R\&D Project Valuation-Empirical Results from a Survey. Research Policy, $35 ; 2006 ; 343-354$.

[32] D. Hartoff, F. M. Scherer, K. Vopel. Exploring the Tail of the Patent Value Distribution. In: O. Granstrand (Ed.), . Economics, law, and intellectual property: seeking strategies for research > Boston/Dordrecht/London: Kluwer Academic Publishing; 2003, pp..> Boston/Dordrecht/London: Kluwer Academic Publishing; 2003, pp.> Boston/Dordrecht/London: Kluwer Academic Publishing; 2003,

[33] F. M. Scherer, D. Hartoff. Technology Policy for a World of Skew-Distributed Outcomes. Research Policy, 29;2000;559-566.

[34] Robert Weinberg, cited in Cell, July 2006

[35] D. Faust. Why Consecutive Years of Flat Funding of the NIH Is Putting a Generation of Science at Risk. Senate Committee on Health, Education, Labor and Pensions. Washington DC, March 11, 2008, cites the Zerhouni quote. 
SU Press 62121091.doc 29

[36] Hall,Bronwin J. Mairesse, P. Mohnen. NBER Working Paper No. 15622; December 2009.

an $1:$ Notes

In October 2010, the Nova Public Broadcasting System television highlighted a

microbiologist, Rachel Collins, who combined science with wrestling. Outside of her

laboratory she was MisChif, champion of the Shimmer female wrestling promotion.

http://www.pbs.org/wgbh/nova/secretlife/scientists/rachel-collins/show/mschif/

ii To the extent that the job market for scientists and engineers clears quickly, the meaning of shortages may simply reflect the desire of employers to hire more scientists and engineers at lower wages. If wages are high and rising, it takes some years for supply to respond, but economics are loathe to call the normal adjustment process a shortage. In 1987 the NSF publicized projections of great shortages of scientists and engineers that turned out to be based more on a desire to increase the supply of scientists so large companies could hire them cheaply than on any realistic analysis of market conditions. Analysts within NSF knew about the weaknesses of the projections but the then director Erich Block ignored their concerns and cited the study in arguments on education, immigration, and employment policy. When this misuse of analysis in science policy was discovered in 1992, Science and Nature editorialized against it and the NSF Director Neal Lane, who took office after the event apologized for the NSF. See, Eric Weinstein How Why Government, Universities, and Industry Create Domestic Labor Shortages of Scientists and High-Tech Workershttp://www.nber.org/ peat/PapersFolder/Papers/SG/NSF.html .

iii The usual division is between drug discovery, in which the firm looks at numerous compounds that may have medicinal value; preclinical trials with animals; and three phases of clinical trials undertaken to obtain Food and Drug Administration (FDA) approval of drugs. 